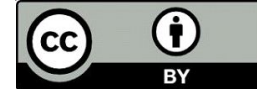

UDC 346.62

LBC 67.402
Submitted: 02.10.2021

Accepted: 18.10 .2021

\title{
COMPARATIVE ANALYSIS OF TERMINOLOGY OF TAX LAW OF RUSSIA AND FRANCE
}

\author{
Alexander I. Goncharov \\ Volgograd State University, Volgograd, Russian Federation
}

Irina S. Zemlyanskaya

Volgograd Institute of Management, Branch of the Russian Presidential Academy of National Economy and Public Administration, Volgograd, Russian Federation

Galina V. Baryshnikova

Volgograd Institute of Management, Branch of the Russian Presidential Academy of National Economy and Public Administration, Volgograd, Russian Federation

Introduction: Russian and French tax legislation presupposes the presence of special terms reflecting taxation processes, therefore, the article raises the question of the initial definition of all terms with the meaning of "tax" and characteristics that determine its economic essence. Everything mentioned above determined the relevance of scientific work and the authors set the aim of conducting a comparative analysis of the terminology of tax law in Russia and France. Methods: the methodological basis of this research is a set of methods of scientific knowledge, among which the main place is occupied by the methods of consistency, analysis, comparative legal and descriptive. Results: the author's position substantiated in the work is based on the tax legislation of Russia and France. Based on a comparative analysis of the norms of the Tax Code of the Russian Federation and the Tax Code of France, a study of the types of tax payments is carried out. The question of the term "tax and collection" is raised. Conclusions: as a result of the study, it was determined that the term "taxes and fees" is used as a generic one, while the preference for establishing various types of taxes and fees applied in Russia and France is given to such a specific term designation as "tax". It was revealed that, despite the use in the tax legislation of France in the name "taxe", "la taxe foncière" is a tax. It has been established that in the Tax Code of the Russian Federation and the Tax Code $\vec{\delta}$ of France, the terms of taxation are used as a means of formalizing the language for special purposes and contribute $\stackrel{2}{?}$ to the establishment and development of legal discourse.

Key words: tax, tallage, taxation, tax law, tax payments, tax legislation.

Citation. Goncharov A.I., Zemlyanskaya I.S., Baryshnikova G.V. Comparative Analysis of Terminology of Tax Law of Russia and France. Legal Concept = Pravovaya paradigma, 2021, vol. 20, no. 4, pp. 72-76. DOI: https://doi.org/10.15688/lc.jvolsu.2021.4.9

\section{СРАВНИТЕЛЬНЫЙ АНАЛИЗ ТЕРМИНОЛОГИИ НАЛОГОВОГО ПРАВА РОССИИ И ФРАНЦИИ}

\section{Александр Иванович Гончаров}

Волгоградский государственный университет, г. Волгоград, Российская Федерация

\section{Ирина Сергеевна Землянская}

Волгоградский институт управления - филиал Российской академии народного хозяйства и государственной службы при Президенте РФ, г. Волгоград, Российская Федерация 


\section{Галина Валерьевна Барышникова}

Волгоградский институт управления - филиал Российской академии народного хозяйства и государственной службы при Президенте РФ, г. Волгоград, Российская Федерация

Введение: российское и французское налоговое законодательство предполагает наличие специальных терминов, отражающих процессы налогообложения, поэтому в статье поднимается вопрос первоначального определения всех терминов со значением «налог» и характеристик, отражающих его экономическую сущность. Все вышеперечисленное обусловило актуальность научной работы, в связи с чем авторами в работе поставлена цель - проведение сопоставительного анализа терминологии налогового права России и Франции. Методы: методологическую основу данного исследования составляет совокупность методов научного познания, среди которых основное место занимают методы системности, анализа, сравнительно-правовой и дескриптивный. Результаты: обоснованная в работе авторская позиция опирается на налоговое законодательство России и Франции. На основании сопоставительного анализа норм Налогового кодекса Российской Федерации и Налогового кодекса Франции проводится исследование видов налоговых платежей. Поднимается вопрос терминообозначения «налога и сбора». Выводы: в результате исследования определено, что терминообозначение «налоги и сборы» используется как родовое, при этом предпочтение при установлении различных видов налогов и сборов, применяемых на территории России и Франции, отдается такому видовому терминообозначению как «налог». Выявлено, что, несмотря на использование в налоговом законодательстве Франции в названии «taxe», «la taxe foncière» является налогом. Установлено, что в Налоговом кодексе Российской Федерации и Налоговом кодексе Франции термины налогообложения используются как средство формализации языка для специальных целей и способствуют установлению и развитию юридического дискурса.

Ключевые слова: налог, сборы, налогообложение, налоговое право, налоговые платежи, налоговое законодательство.

Цитирование. Гончаров А. И., Землянская И. С., Барышникова Г. В. Сравнительный анализ терминологии налогового права России и Франции // Legal Concept = Правовая парадигма. - 2021 . - T. 20, № 4. С. 72-76. (На англ. яз.). - DOI: https://doi.org/10.15688/lc.jvolsu.2021.4.9

\section{Introduction}

A comparative analysis of tax terminology in modern Russian and French languages in the presented work will be carried out on the basis of the authentic texts of the tax legislation of the Russian Federation and France. In Russia, the Tax Code of the Russian Federation (RF Tax Code) is the main normative legal act governing domestic tax legislation. The Tax Code of the Russian Federation consists of two parts. The first part of the Tax Code of the Russian Federation, which entered into force on January 1, 1999, is a general part and contains:

- general concepts, terms, principles and rules of taxation;

- norms that imply responsibility for noncompliance with the law, a list of measures of influence on violators of the law;

- the competence of various subjects of tax relations;

- the rights and obligations of all, without exception, participants in tax relations.

The second part of the Tax Code of the Russian Federation, which entered into force on
January 1, 2001, is a special part that regulates: permissible and directly established taxes, duties and fees with a description of the procedure for their calculation and payment; terms of payment of taxes, fees and duties; special tax regimes; benefits, etc.

The creation of the French Tax Code (Code général des impôts ou CGI) was accompanied by the adoption of four Decrees and one Ordinance of April 6, 1950. A summary of the Code général des impôts is presented in Table 1.

In accordance with clause 1 of Article 8 of the Tax Code of the Russian Federation, tax is understood as a mandatory, individually free payment levied from organizations and individuals in the form of alienation of funds belonging to them by right of ownership, economic management or operational management of funds in order to financially support the activities of the state and/ or municipalities [1].

Clause 2 of Article 8 of the Tax Code of the Russian Federation states that the levy is a compulsory fee levied from organizations and individuals, the payment of which is one of the conditions for the payment of levies by state 
bodies, local self-government bodies, other authorized bodies and officials of legally significant actions, including the granting of certain rights or the issuance of permits (licenses), or the payment of which is conditional on the implementation of certain types of entrepreneurial activity within the territory where the levy was introduced.

Clause 1 of Article 12 of the Tax Code of the Russian Federation states that the following types of taxes and fees are established in the Russian Federation: federal, regional and local. In accordance with Article 13 of the Tax Code of the Russian Federation, federal taxes and fees include:

1) value added tax;

2) excise taxes;

3) personal income tax;

4) corporate income tax;

5) tax on the extraction of minerals;

6) water tax;
7) fees for the use of objects of the animal world and for the use of objects of aquatic biological resources;

8) state duty;

9) tax on additional income from the extraction of hydrocarbons.

Article 14 of the Tax Code of the Russian Federation establishes the following regional taxes:

1) tax on property of organizations;

2) tax on gambling business;

3) transport tax.

Article 15 of the Tax Code of the Russian Federation states that local taxes and fees are:

1) land tax;

2) tax on property of individuals;

3) trade fee [1].

In addition to the listed federal, regional and local taxes and fees, the tax legislation of Russia, in particular Article 18 of the Tax Code of the

\section{Summary of the French Tax Code (Code général des impôts) as of October 15, 2021 translated into English}

\begin{tabular}{|c|c|}
\hline La courte structure du Code général des impôts & English translation \\
\hline Livre premier: Assiette et liquidation de l'impôt & Book One: Taxable Base and Tax Calculation \\
\hline Première Partie: Impôts d'État & Part one: government taxes \\
\hline Titre premier: Impôts directs et taxes assimilées & $\begin{array}{l}\text { Document One: Direct Taxes and Similar Direct Taxes } \\
\text { (includes } 4 \text { chapters) }\end{array}$ \\
\hline Titre II: Taxes sur le chiffre d'affaires et tax es assimilées & $\begin{array}{l}\text { Second Document: Sales Tax and Similar Taxes (includes } \\
22 \text { chapters) }\end{array}$ \\
\hline $\begin{array}{l}\text { Titre II bis: Dispositions communes aux impôts directs et } \\
\text { aux taxes surle chiffre d'affaires }\end{array}$ & $\begin{array}{l}\text { Document Two Bis: General Provisions on Direct and Value } \\
\text { Added Taxes (includes } 4 \text { chapters) }\end{array}$ \\
\hline Titre III: Contributions indirectes et taxes diverses & $\begin{array}{l}\text { Document Three: Indirect Taxes and Fees (includes } \\
4 \text { chapters) }\end{array}$ \\
\hline $\begin{array}{l}\text { Titre IV: Enregistrement, publicité foncière. Impôt de } \\
\text { solidarité sur la fortune, timbre }\end{array}$ & $\begin{array}{l}\text { The fourth document: Registration, real estate transactions. } \\
\text { General property tax, stamp duty. (includes } 4 \text { chapters) }\end{array}$ \\
\hline Titre V: Dispositions communes aux titres I, II et IV & $\begin{array}{l}\text { Fifth document: general provisions for documents I, II and V } \\
\text { (consists of one chapter) }\end{array}$ \\
\hline $\begin{array}{l}\text { Deuxième Partie: Impositions perçues au profit des } \\
\text { collectivités locales et de divers organismes }\end{array}$ & $\begin{array}{l}\text { Part two: tax es levied on local collective organizations and } \\
\text { other organizations }\end{array}$ \\
\hline Titre premier: Impositions communales & Document One: Taxation of Communes (includes 4 chapters) \\
\hline Titre II: Impositions départementales & $\begin{array}{l}\text { Second Document: Taxation in Departments (includes } \\
2 \text { chapters) }\end{array}$ \\
\hline $\begin{array}{l}\text { Titre 0-II bis: Imposition percues au profit de la métropole } \\
\text { de Lyon }\end{array}$ & $\begin{array}{l}\text { Document 0-II bis: Taxes Collected in the City of Lyon } \\
\text { (Includes } 2 \text { Chapters) }\end{array}$ \\
\hline $\begin{array}{l}\text { Titre II bis: Impositions perçues au profit des régions et de la } \\
\text { collectivité territoriale de Corse }\end{array}$ & $\begin{array}{l}\text { Second Bis Document: Taxes Levied in Areas and } \\
\text { Collective Territorial Authorities of Corsica. (includes } \\
3 \text { chapters) }\end{array}$ \\
\hline $\begin{array}{l}\text { Titre III: Impositions perçues au profit de certains } \\
\text { établissements publics et d'organismes divers }\end{array}$ & $\begin{array}{l}\text { The third document: taxes levied in favor of some } \\
\text { government agencies and various organizations. (includes } \\
4 \text { chapters) }\end{array}$ \\
\hline $\begin{array}{l}\text { Troisième partie: Dispositions communes aux première et } \\
\text { deuxième parties }\end{array}$ & Part three: general provisions to the first and second parts \\
\hline Livre II: Recouvrement de l'impôt & Oollecting Taxes (consists of four chapters) \\
\hline
\end{tabular}

Note. Source. Compiled and translated by the authors based on materials [2]. 
Russian Federation, provides for the use of special tax regimes, which may provide for a special procedure for determining the elements of taxation, as well as exemption from the obligation to pay certain taxes and fees provided for Articles 13, 14 and 15 of the Tax Code of the Russian Federation. Special tax regimes include:

1) the system of taxation for agricultural producers (unified agricultural tax);

2) a simplified taxation system;

3) the system of taxation in the implementation of production sharing agreements;

4) patent taxation system;

5) tax on professional income (as an experiment).

\section{Research on the terminology of tax law in Russia and France}

In the Tax Code of the Russian Federation, the system of tax payments is represented by such basic terms as tax and collection. However, in accordance with the above articles of the Tax Code of the Russian Federation, such terms as excise and duty also apply to taxes and fees. The study of the norms of the Tax Code of the Russian Federation allows us to conclude that the term "taxes and fees" is used as a generic term, while preference is given to such a specific term designation as "tax" when establishing various types of taxes and fees applied on the territory of Russia.

French tax law uses terms such as:

1. Impôt (m) - tax, "Prélèvement effectué d'autorité et à titre définitif sur les ressources ou sur les biens des individus ou des collectivités, et payé en argent pour subvenir aux dépenses d'intérêt général de l'État ou des collectivités locales".

2. Taxe (f) - tax, duty, "Prélèvement à caractère fiscal, destiné à alimenter la trésorerie de l'État, d'une collectivité locale ou d'un établissement public administratif en contrepartie d'un service rendu aux administrés".

3. Contribution (f) - contribution, "Part que chacun apporte à une dépense commune, et en particulier aux dépenses de l'État ou des collectivités publiques (au pluriel surtout)". Synonyms for this tax term are: droit, imposition, taxe.
4. Prélévement (m) - sampling, "Prélèvements obligatoires, ensemble des charges fiscales et sociales grevant les contribuables".

5. Cotisation (f) - contribution, "Contribution des salariés et/ou de leurs employeurs versée aux différents organismes qui assurent la protection sociale (la Sécurité sociale, l'assurance chomage, etc.)".

6. Redevance (f) - Royalty fee, "Somme due en contrepartie de l'utilisation d'un service public: Payer la redevance de la télévision".

7. Droit (m) - fee, "impôt, taxe: Payer des droits sur les alcools".

8. Participation (f) - participation, "contribution" [3].

In French tax law, as well as in Russian tax law, the term "impôt" (tax) is a generic term.

The term "tax" in France was defined thanks to judicial practice, in particular, by the decision of the State Council of the "National Union of Air Carriers" dated November 21, 1958. This decision identified the following five characteristics that define the economic term "tax":

- the tax is collected in cash;

- established by the state;

- has a permanent character of collection;

- tax revenues are directed to government purposes;

- the tax is free of charge.

For example, taxes include: "l'impôt sur le revenue" (income tax), "la taxe foncière" (land tax), "l'impôt sur les societies" (corporate income tax).

\section{Conclusion}

Despite the use of "taxe" in the name, "la taxe foncière" is a tax.

The use of "taxe" in the name of a tax payment is usually associated with the provision of government services [4].

The study also allows us to conclude that in the main regulatory legal acts governing the tax legislation of both Russia and France, the terms of taxation are used as a means of formalizing the language for special purposes and contribute to the establishment and development of legal discourse.

In our subsequent studies, in order to establish a possible correlation and clear differences between the use of Russian and French equivalents of tax law terms, we aim to investigate the 
definitions of the above terms and analyze the situations of their use in Russian and French.

\section{СПИСОК ЛИТЕРАТУРЫ}

1. Налоговый кодекс Российской Федерации (часть первая) от 31.07.1998 № 146-Ф3 (ред. от 02.07.2021). - Электрон. текстовые дан. - Режим доступа: https:/www.nalogovyy-kodeks.ru (дата обращения: 02.10.2021). - Загл. с экрана.

2. Code Général des Impôts. - Electronic text data. - Mode of access: https://www.legifrance.gouv.fr/ (date of access: 02.10.2021). - Title from screen.

3. Définitions: Fiscalité-Dictionnaire de Français Larousse. - Electronic text data. - Mode of access: https://www.larousse.fr/dictionnaires/francais/fiscalité/ 33867 (date of access: 02.10.2021). - Title from screen.

4. Quelle-est la Différence Entre Taxe, Impôt et Redevance? - Electronic text data. - Mode of access: https://www.pointdroit.com (date of access: 02.10.2021). - Title from screen.

\section{REFERENCES}

1. Nalogovyy kodeks Rossiyskoy Federatsii (chast' pervaya) ot 31.07.1998 № 146-FZ (red. ot 02.07.2021) [Tax Code of the Russian Federation No. 146-FZ (Part 1) Dated July 31, 1998 (As Amended on July 2, 2021)]. URL: https://www.nalogovyykodeks.ru (accessed 2 October 2021).

2. Code Général des Impôts. URL: https:// www.legifrance.gouv.fr (accessed 2 October 2021).

3. Définitions: Fiscalité-Dictionnaire de Français Larousse. URL: https://www.larousse.fr/ dictionnaires/francais/fiscalité/33867 (accessed 2 October 2021).

4. Quelle-est la Différence Entre Taxe, Impôt et Redevance? URL: https://www.pointdroit.com (accessed 2 October 2021).

\section{Information About the Authors}

Alexander I. Goncharov, Doctor of Sciences (Jurisprudence), Doctor of Sciences (Economics), Professor, Department of Civil and Private International Law, Volgograd State University, Prosp. Universitetsky, 100, 400062 Volgograd, Russian Federation, gimchp@volsu.ru, goncharova.sofia@gmail.com, https://orcid.org/0000-0001-6580-4104

Irina S. Zemlyanskaya, Candidate of Sciences (Economics), Associate Professor, Department of Accounting, Analysis and Audit, Volgograd Institute of Management, Branch of the Russian Presidential Academy of National Economy and Public Administration, Gagarina St, 8, 400066 Volgograd, Russian Federation, zemlyanskaya-is@vlgr.ranepa.ru, https://orcid.org/0000-0001-8642-045X

Galina V. Baryshnikova, Candidate of Sciences (Philology), Associate Professor, Department of Linguistics and Intercultural Communication, Volgograd Institute of Management, Branch of the Russian Presidential Academy of National Economy and Public Administration, Gagarina St, 8, 400066 Volgograd, Russian Federation, barychnikova-gv@vlgr.ranepa.ru, https://orcid.org/0000-0003-4823-6453

\section{Информация об авторах}

Александр Иванович Гончаров, доктор юридических наук, доктор экономических наук, профессор, профессор кафедры гражданского и международного частного права, Волгоградский государственный университет, просп. Университетский, 100, 400062 г. Волгоград, Российская Федерация, goncharova.sofia@gmail.com, gimchp@volsu.ru, https://orcid.org/0000-0001-6580-4104

Ирина Сергеевна Землянская, кандидат экономических наук, доцент кафедры бухгалтерского учета, анализа и аудита, Волгоградский институт управления - филиал Российской академии народного хозяйства и государственной службы при Президенте РФ, ул. Гагарина, 8, 400066 г. Волгоград, Российская Федерация, zemlyanskaya-is@vlgr.ranepa.ru, https://orcid.org/0000-0001-8642-045X

Галина Валерьевна Барышникова, кандидат филологических наук, доцент кафедры лингвистики и межкультурной коммуникации, Волгоградский институт управления - филиал Российской академии народного хозяйства и государственной службы при Президенте РФ, ул. Гагарина, 8, 400066 г. Волгоград, Российская Федерация, barychnikova-gv@vlgr.ranepa.ru, https://orcid.org/0000-0003-4823-6453 